\title{
Development of methods and practices of virtual reality as a tool for participatory urban planning: a case study of Vilnius City as an example for improving environmental, social and energy sustainability
}

Gintaras Stauskis

\begin{abstract}
Background: Multiple channels of sustainable urban development could be managed in the process of an inter-disciplinary cooperation and creative involvement of all stakeholders. The paper aims to verify how the specific methods of virtual reality simulation could be used as an effective tool for setting an efficient participation platform between the stakeholders to improve environmental, social and energy sustainability of urban development in modern cities. The paper is based on the case study of Vilnius City.

Methods: The article shows how innovative tools could facilitate better cooperation based on more balanced approaches in participatory urban planning by chronological review of traditional public involvement practices and structured analysis of emerging public participation techniques. As each discipline involved in sustainable urban development covers specific socio-economic, environmental, economic and creative competence fields, it is essential to develop a comprehensive tool for public participation that is well accessible, reliable and efficient.

Results: The provided analysis of research theories and practical applications of public involvement through virtual simulation in the case of Vilnius City shows that virtual reality and spatial modelling integrated on gaming platforms under the conditions of widespread information and communications technology (ICT) applications could be developed and used as an innovative, involving and efficient tool for facilitating wider and more effective public involvement in the planning and design of urban environment and so increase social and environmental sustainability of urban development process. The application of this method for planning public spaces leads to more efficient use of environmental resources also reducing the need for primary energy and using it more rationally.

Conclusions: The analysis of using virtual urban simulation (VUS) method for representing, analysing, referring and improving urban design projects reveals that virtual applications can make public participation more accessible for citizens of the community and improve reliability of its results thus having direct impact on the planning process and its outcomes in terms of more sustainable impact on environmental and economic development of urban community.
\end{abstract}

Keywords: Urban planning; Landscape; Virtual reality; Public participation; Stakeholder involvement 
Tell me, I forget,

Show me, I remember,

Involve me, I understand,

Step back, I will act.

Old Chinese proverb

\section{Background}

\section{Emerging public participation}

The public initiatives that emerged in the early 70 s in the UK and other European countries are good cases to analyse and illustrate how public participation gradually turned into an instrument of urban planning and design as we understand and use it today. The post-war policy of rebuilding the ruined blocks in big British cities turned into the method of urban renewal when the entire residential areas were pulled down on the reason of low sanitary quality and the goal of rising living standards. In reality, this brought demolition of old development in Birmingham, Manchester, Glasgow and other cities. That process of 'improving' was additionally fuelled by rising income of urban councils as a result of relatively dynamic economic development [1]. Several drawbacks of this urban policy were fast to appear. On the one hand, valuable urban legacy was destroyed; the entire urban communities with specific lifestyles and cosy neighbourhoods were completely erased. On the other hand, the modernist style of concrete blocks that appeared on their former land sites were sold fast but appeared to be disgusting to live in and were abandoned in a short term by their residents turning the whole areas into urban deserts. Last but not least, complete rebuilding was a very costly venture compared to gradual refurbishment of existing stock. The process of protests of local residents was fast to appear, and it was professionally supported by architects (Figure 1). In Manchester, an architect Rod Hackney and his neighbours established a Black Road Area Action Group to protect historic residences from demolition and went into a massively supported campaign of debates with the city council called 'Save my house' in 1972.

The success of a particular case in Manchester turned into a precedent for the whole country that led to wider discussions on the issues of urban redevelopment between the residents and the councils. The case of hearing local residents and then setting the refurbishment strategies was finally formalised and included into the UK's housing law. Still, efficient methods of communication between the clerks, the public and the business were to be developed. In Europe, many countries have gone through a similar process like in the UK in approximately the same decade. As a matter of fact, modern public participation methods were not used in East European countries until the last decade of the twentieth century for evident socio-political reasons. Finally, regulations on public involvement found their stake in national construction law mostly following the examples of other West European countries. In general perspective, public participation facilitates decisions on more rational planning and design thus saving material and social resources including urban land, materials, labour and energy.

\section{Methods}

The paper is designed as a set of analysed practices and case studies with public participation in planning. Techniques and potentials of spatial modelling and virtual representation are reviewed and analysed. The research starts by presenting the development of techniques in virtual representation and turning them into a planning tool. Virtual simulation in gaming environment is analysed by presenting several case studies including the one developed by the author of this paper. By comparing different tools and methods used for public participation, their strengths and weaknesses are identified. By comparative analysis, passive, active and interactive public
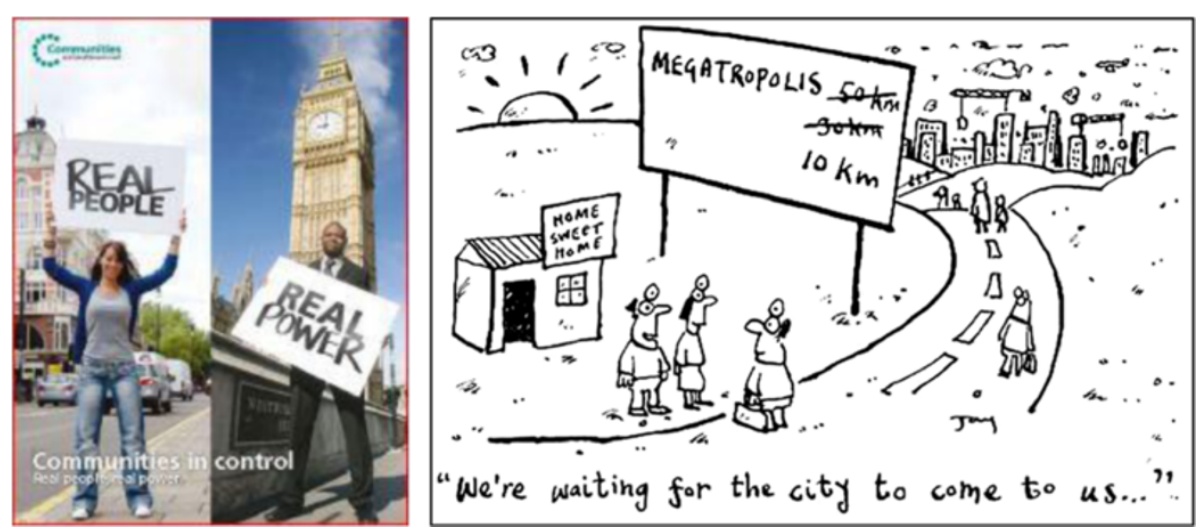

Figure 1 Residents looking for real participation power in urban redevelopment of the UK. Real people need real power before Megatropolis strikes their home. Images: Communities in Control [2]; http://www.ourpatch.com.au/system/attachments/0003/3949/Megatropolis.jpg. 
participation methods are structured in the aspect of their interactivity. As a conclusion, the recommendations are drawn on how to apply and replicate innovative information and communications technology (ICT)based public participation tools for better results in urban development.

\section{Research of virtual reality applications in urbanism}

Since the first papers were published on research in virtual reality and space simulation in 1989, the immense list of publications is available, illustrating the scope of research activities ongoing in different knowledge centres around the globe [3]. As noted by Simpson in 2001, the published research primarily focused on general issues of environment simulation later calling for application of virtual reality in planning and design as well as analysing current examples and the role of urban simulation [4]. Along that road, the aspects of urban simulation in geographic information system (GIS) environment were analysed, reflecting state of the art in virtual urban modelling. Applications of simulation for hazard research are one more area for research. Wider development of research on virtual reality applications in urbanism collide with technical limitations of both hardware and software, as well as lack of established research methodology. The most advanced research centres focus on the complex research of three-dimensional city scale simulation in a GIS environment also combining it with dynamic building of integrated modelling systems. Several main topical categories of references in virtual reality simulation could be identified. Urban and environmental simulation is a broad area covering references in urban and environmental simulation, visualisation and virtual reality, focusing on contributions to urban planning. Virtual reality and GIS application is another field for researchers whose centre of their glance is on virtual reality and urban simulation as it is developed in GIS environment. Urban and regional modelling by building, evaluating and testing urban and regional development models is the next broad category of references. Urban simulation and gaming section explores simulation and technical aspects of gaming. Technical aspects of urban and environmental simulation are common category of research being presented independently or incorporated into one of the abovementioned categories.

Virtual reality models are different from reality, so it is an impression of a person involved in experiencing virtual reality. There are important aspects of human perception of the presence in virtual models that empower human senses as memory, bodily movement and kinesthesis [5]. The sets of parameters such as awareness, memory, sensory notion, feeling of realism, attention and interaction are offered to identify the notion of mixed presence of the user in virtual models.

\section{Stakeholder involvement as planning method}

Special regulation adopted in the UK for developing a statement of community involvement (SCI) in urban planning allows the local government to set a goal in endorsing this regulation, to fulfil its vision in order to engage the people and organisations of Sheffield in planning for sustainable development [6]. The experienced benefits of exercising this practice in Sheffield, the third largest metropolitan district in the UK, promote planning as a proactive tool for delivery of sustainable development, reflection of needs of local community, quality improvement and efficiency of planning as well as promotion of social cohesion by giving communities a tangible steak in decision making. The involvement covering public, private, community and voluntary sectors of local urban settlements has to be transparent, promoting real participation and involvement, accessible and inclusive, also accountable. The principles of SCI stated hereby include culture of engagement, early and continuous involvement, reaching out and fit for purpose, clarity and formal representation based on a certain code of practice. Several participation tools are identified to be applied by SCI: media, letters, public meetings, websites, distributed documents, exhibitions and questionnaires. Continuing the involvement, using its results and giving feedback on implementation are most important aspects for local communities.

The stages of SCI are evolving in the process of its undertaking as more cooperation experience is accumulated by the stakeholders. Starting with informing local residents about the planning process that is going to happen, it moves to the next phase: consultation of local residents and survey of their opinions, and further on, it leads to active involvement of communities in becoming a stakeholder and partner of the planning process [6]. The necessity to consider the needs and expectations of all citizens' groups is meant as 'equality', an aspect which is important for the residents of all groups to believe that the participation process is legitimate and timely organised where the results are used for the public interest [7].

As underlined by the International Association of Public Participation in their project aimed at the improvement of cross-cultural exploration of public governance and decision making, innovative use of communication technology can improve the quality of public participation with indigenous communities who have much better perception of simulated images compared to twodimensional maps and drafts [8].

However, several decades of applying traditional tools to involve the public into the planning turned out to be restricted in terms of access and time, transparency of the process as well as needed resources. Different types of meetings, committees and working groups spend much time as participants have little practice in understanding planning strategies, the process itself and its outcomes. 
Additional time is needed to access all groups of citizens, especially the teenagers and the youth. The meetings involving the members of local communities are usually dominated by few most active members who reveal their own opinion more than that of the whole community. It happens that these 'activists' have some motivated interest in the outcome of planning in terms of market competition, and so transparency becomes an issue difficult to control. Multiple meetings, repeated access attempts and the need to control the process involve professional staff, premises and services; therefore, the process usually becomes long and expensive compared to its results.

Several of the above-mentioned methods are practiced in Lithuania as regulated by the Guidelines for Public Participation in Urban Planning [9]. Public participation is outlined therein as 'Voluntary participation of legal and private entities and their groups in preparation of territorial planning document'. Providing information about the goals of planning on the Internet and in local paper, placing it at the local authority's premises, making an exhibition of the project and holding public hearings are the main activities required by the code. Completed planning projects are registered by the local authority at the publicly accessible Planning Register. Time frames for different stages of informing and involving the public depend on a scale of planning: for general plans, that in Lithuania's case covers big urban areas, and all spatial, social and environmental aspects' time intervals are longer; for special plans, covering some specific planning aspects, time intervals are relatively shorter (Table 1).

The practice of implementing participatory planning methods in Lithuania has demonstrated quite similar limitations as in the other countries, transparency and efficiency being the main ones. There were cases when organised groups of community representatives have severely criticised selected development projects but later supported similar ideas presented by another developer. Citizen's groups often act against everything and

\begin{tabular}{|c|c|c|}
\hline $\begin{array}{l}\text { Type of plan/time } \\
\text { span for procedures }\end{array}$ & General plan & Special plan \\
\hline \multirow{2}{*}{$\begin{array}{l}\text { Information for citizens } \\
\text { about planning procedures }\end{array}$} & Immediately & Immediately \\
\hline & $\begin{array}{l}\text { Letters to owners, } \\
\text { residents, companies }\end{array}$ & $\begin{array}{l}\text { Letters to owners of } \\
\text { neighbouring and } \\
\text { planned plots }\end{array}$ \\
\hline $\begin{array}{l}\text { Getting acquainted with } \\
\text { plan }\end{array}$ & 1 month & 20 working days \\
\hline Public exhibition time & 15 working days & 10 working days \\
\hline Public meeting & $\begin{array}{l}10 \text { working days in } \\
\text { advance }\end{array}$ & $\begin{array}{l}10 \text { working days in } \\
\text { advance }\end{array}$ \\
\hline $\begin{array}{l}\text { Complains accepted from } \\
\text { public }\end{array}$ & 1 month & 1 month \\
\hline
\end{tabular}

anything without a constructive dialogue, and for this reason, the architects in Lithuania are very modest developing more interactive dialogue and tend to have just formal procedures usually limited to a purely bureaucratic paperwork of announcements, protocols and reports. In this case, the real voice of residents remains unheard.

Accountability of planning organisers and transparency of planning process are the main social gains that are generated in the process of public participation as noted by the EU Directive on Public Participation [10]. Involvement of groups of residents and other NGOs is especially encouraged as it brings also environmental education for people. Wider use of electronic media is appreciated by the Directive as one of the means for appropriate information and involvement.

The basic methods used for public participation based on their interactivity are structured as passive, active and interactive (see Table 2). Passive methods are based mainly on one-way communication between the planners and the public as one of the stakeholders with no interactivity. Active methods have some elements of interactivity as they try to establish 'a dialogue' instead of 'a monologue'. The emerging ICT-based techniques are attributed to interactive methods as their goal provides a person or representative group with possibilities of direct access and reliable and monitored feedback on the goals, roles, process and consequences of planning.

Present challenges in urban development and limitations of traditional participation methods in Vilnius City were the reasons of looking for new more efficient methods of public participation in urban planning and design. Numerous cases popped out in recent years in Vilnius City when centrally prepared development programmes and projects met severe opposition from urban residents: demolition of old housing units at Šnipiškès area close to modern skyscrapers (Figure 2a); protest of Pilaite housing district residents against the municipality's plan to urbanise recreation area at a local lakeshore (Figure 2b). These protests left local authorities confused and city planners disappointed. On the other hand, attempts of planners, architects and authorities to establish a constructive dialogue with the residents practically failed because of lack of experience from both sides as well as the proposed methods showed up as inefficient and non-transparent.

Analysis of the analysed cases shows that the attempts to maintain a contact with local residents and involve them in planning were carried out in primitive ways by using just formally required methods with no follow-up and real impact on the planned development projects. There were several cases during the last years when certain urban development programmes and decisions of city bureaucrats that were not supported by a part of Vilnius citizens ended with social protest of local communities. 
Table 2 Structure of public participation methods in urban planning and design

\begin{tabular}{llll}
\hline Method & Passive & Active & Interactive \\
\hline Preparatory & Data collection & Field study, Interviews & Internet, websites \\
Analytic & Case study analysis, survey & Working groups & Policy dialogue \\
Disseminative & Printed material & Presentation, visualisation & Open space technology, gaming and multiplayer \\
Monitoring & Observation & Committees, meetings, test audit & E-government, virtual urban simulation \\
\hline
\end{tabular}

On the other hand, just the real cases when citizen's rights to make impact on city development are violated cause active informal actions during which the civil society builds up and real participation experience is developed. Also, this encourages local authorities who act as planning organiser to seek for more efficient participation tools to transparently involve all citizens' groups into a dialogue with planners and thus increase planning quality and make positive impact on the city development.

Some cases show how Internet databases used as virtual knowledge platforms with good access have attracted big number of community and professional users who generate their feedback referring to the presented planning and design information in the way of direct comments on website also that brings learning and replicating the provided practices in a wider scale. Sustainable energy innovations that were applied at Grand Spa Lietuva hotel and spa complex in Druskininkai town in Lithuania (Figure 3a) were presented on the sustainable building platform Construction 21 [11]. In relatively short time, that attracted lots of virtual visitors nationwide who analysed the provided information and left the feedback. What is more, by reviewing information on the newly refurbished spa complex in the famous Lithuanian resort, town citizens learned about the benefits of innovative smart grid system for residential areas. This triggered interest in replicating such practices and increased visibility of professionals who have designed, installed and are maintaining these facilities. All this was made possible by providing virtual access to urban development cases for the community users on the Green Building platform Construction21. It turned out that the provided information is easier to access and better to understand when presented in a virtual way with simulated architectural images and supplemented by technical data.

Innovative public involvement systems also cover energy and climate issues that are the major challenges in modern communities especially in creating urban complexes of nearly zero-energy buildings (Figure 3a). In the above-mentioned case, with quite limited interactivity, the citizens demonstrated their interest in the newly built up facility, it could be expected that even greater interest would emerge when the future development would be presented in the form of virtual immersive models with interactive user's interface. This approach is illustrated below.

Virtual reality is more and more often used as a planning tool. Visualisation of planning and design material gives an important planning support in landscape architecture design. Virtual reality models allow the citizens to understand spatial and temporal processes of design; they encourage communication and comprehend planning proposals. Testing the virtual reality (VR) models in three-dimensional (3D) spatial design showed that $2 \mathrm{D}$ models and aerial photos are also needed to support orientation on-site, and the best results are achieved by combining these tools together. The virtual models offered to the public are preferred to be realistic but not too photo-realistic as fancy details and other visual

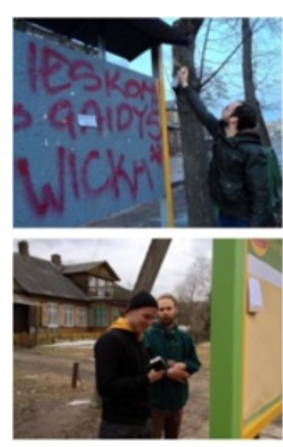

a

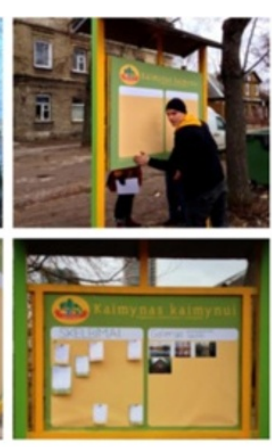

b

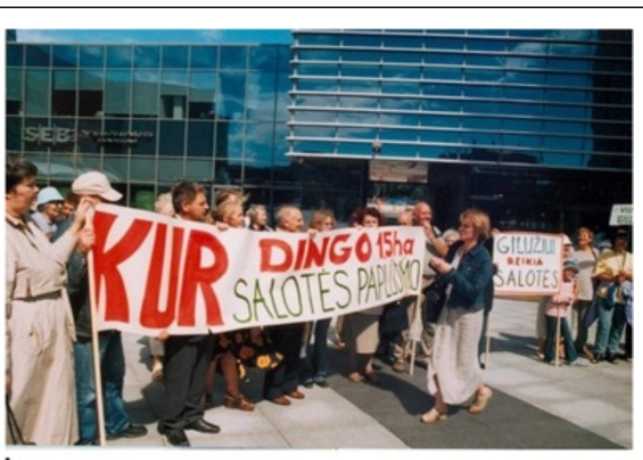

Figure 2 Resident's initiative and public meeting. (a) Resident's initiative - a dashboard at Šnipiškès neighbourhood, 2012. Image: http://laimikis.lt/ snipiskieciai-kaimynu-lenta-fino-gatve/. (b) Public meeting of Pilaitės local community, Vilnius, Lithuania, 2011. Image: http://www.pilaitesbendruomene. It/istorija.html. 

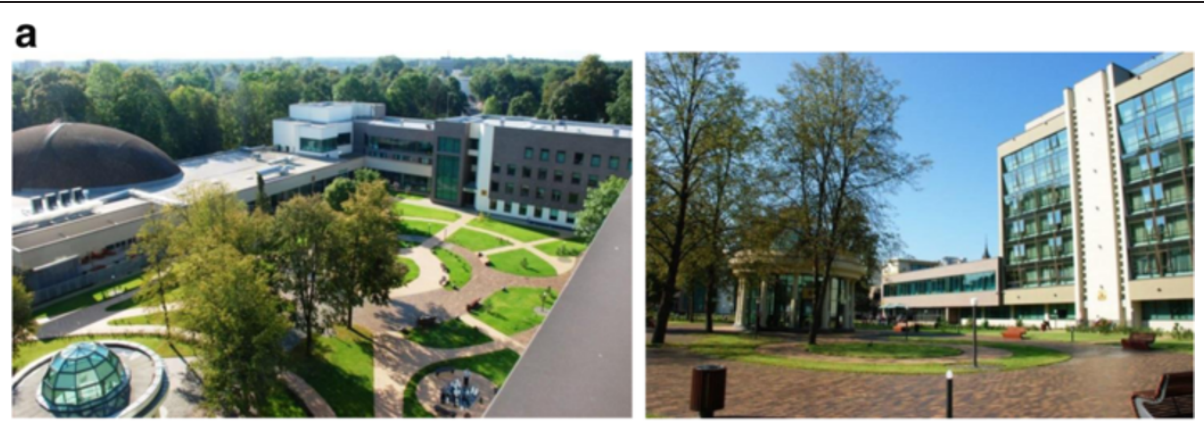

b

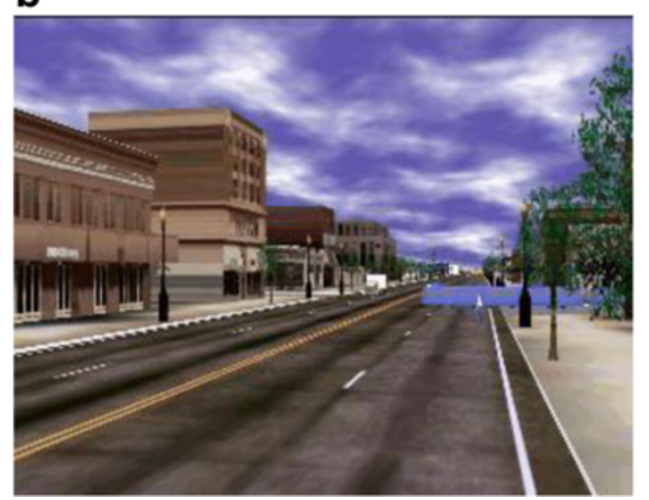

Figure 3 Grand Spa Lietuva hotel and detailed urban model. (a) Grand Spa Lietuva hotel, conference centre and spa complex in Druskininkai, Lithuania. Green Building platform: www.construction21.eu. Pictures by G. Stauskis. (b) Detailed urban model with automated vehicles and pedestrians [12].

effects distract attention instead of focusing on essential features of a site. Visualisation sparks public interest in planning proposals, while a balance of live VR shows and Internet visits should be maintained. The development of the planning proposal in time is of a great interest both to the public and professionals which is already a 4D task for future development that enables to show and see 3D spatial planning that changes in a particular time frame (Figure 3b) [12].

Possible applications of virtual urban simulation include projects with public involvement into presenting, analysing and evaluating urban development models. Interactive tools provide residents with possibility to get a close look at the projects to understand the concept and feedback their opinions. The virtual urban simulation (VUS) system in association with GIS involves more data about the area and the residents such as land plot data, availability of government redevelopment grants and resident's characteristics including willingness to participate in area redevelopment process. By linking VUS and GIS, it is easy and comfortable for the user to access all types of required information by highlighting it or identifying in other ways. On the other hand, it is doubtful that availability of the mentioned data layers and accessing it in real time will automatically generate information about the suitability of particular land parcels for redevelopment [12].
Effective visual representation of designed models gets especial importance in landscape architecture. It was experienced by the researchers of interactive landscape planning project in Koenigsluter am Ulm (Germany) that the integration of innovative media tools with participation methods in planning process allows achieving better citizen's understanding and higher participation rates [13]. The platform comprised open-source components turned to be efficient for individual implementation depending on the specifics of the project and real needs of the community.

Some space simulation systems enable the user to modify the urban development model: change houses, trees and other elements from the designed library. The option of change of the area in time is especially a useful feature for local community residents, e.g., experiencing the change of landscape in time how trees grow up and streetscape changes over time. Linking these applications to real estate information as land plot costs makes them especially useful. Some systems build their efficiency on features as generating development of the area by selecting houses through a typical prototype library as practiced in Los Angeles, CA, USA.

SimCity video game series which started in 1989 is recognised as one of the first virtual urbanism gaming applications that besides its gaming aspects bears a didactic role 
that is being used in several urban training practices around the world. Since spatial modelling tools were developed, they adhere to similar features of gaming products, e.g. graphical features, user interfaces, multi-level interaction and others. Some agent-based modelling features are presented as conceptual gaming tools [14]. Video games are more and more important as spatial modelling tools and simulation engines able to analyse socio-spatial and hierarchical systems of modern urban environment both in real and designed cases. Still, video games and simulation models implement rules based on different and even opposite methods: complex models explicitly expose possible choices and their interrelations, while in video games, the user has to discover the rules of the play himself. On the other hand, video games are appealing and pleasant because of their graphic features and interactive scenarios that are more involving and attractive for the user.

\section{Virtual simulation and gaming in urban context}

Being a way of learning about the world in general and learning new knowledge in particular, gaming has several great advantages of applying virtual simulation tools for public interaction and, in particular, for participation reasons. Firstly, it is an immediate report of behavioural and emotional status of a participating subject to the system. That allows recording extremely reliable information about the user's opinion without distortion of results for the reasons of delay in time, location, emotional status, different context and other casual circumstances. Second, it is attractiveness and involving a sense of gaming that erases the barriers of age, gender, social experience and others. Thirdly, ICT application provides equal and easy access to the information regardless of time and location.

Virtual simulation is used to facilitate stakeholder involvement in the projects of very different nature. While establishing a multi-stakeholder platform for sustainable urban mobility, the method of simulation is envisaged as one of the important tools for public involvement into presenting, evaluating and even designing urban mobility systems [15]. They are used in order to better understand dynamic interactions of communities within and with each other, as an integral part of involving community into strategic development of the Chicago North Illinois Planning Commission to achieve citizen's participation in many innovative ways. The network of stationary and mobile devices is involved into polling and analysing mobility planning results by using a 'Paint the Town' programme where residents could designate areas for future development or redevelopment, visualise future land uses and track its impact on transportation, housing, economy, environment and other sectors of the city life (Figure 4). All the presented methods are used to turn

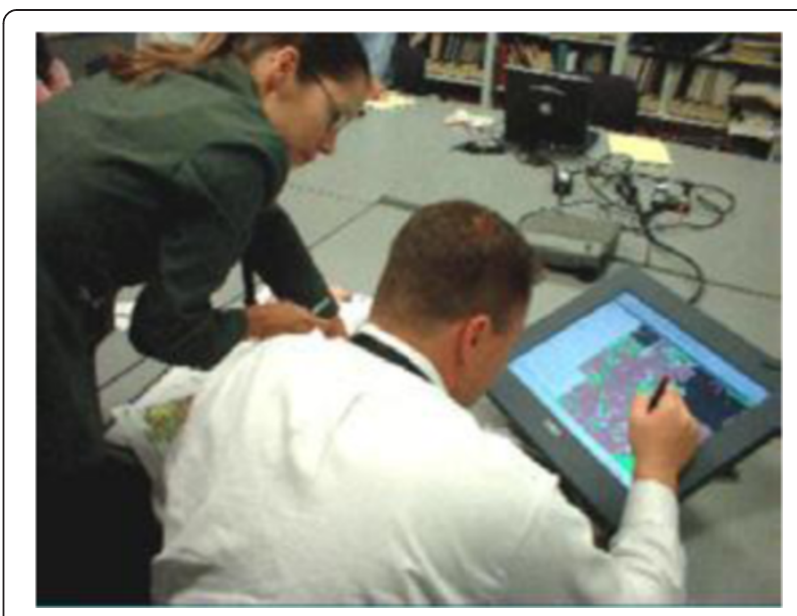

Figure 4 Community members using 'Paint the Town' technology to design and track changes in mobility of Chicago, IL, USA, 2013. Image: http://www.internationaltransportforum.org/ IntOrg/ecmt/urban/Washington03/Thomas.pdf.

usual PC gaming applications from entertaining leisure activity to a creative tool that - in our article's case - is used for the tasks of urban design and architecture.

ICT-based gaming tools used to specifically involve youth in the urban planning process activate the specific segment of citizens that are often ignorant of urban policies as long as they stay aside of the youngster's life. The application of Minecraft Block by Block as an ICT tool for young people can show planners how they would like to see their city's public spaces, residential and recreation areas look like in the future [16]. The partnership of the UN-Habitat, Swedish Building Services and the gaming company aims to give the youth greater appreciation of how sustainable urban development could be integrated into their cities.

\section{Virtual urban simulator for public participation}

The methodology of public participation presented hereby has been developed at the Department of Urban Design at Vilnius Gediminas Technical University (VGTU), Lithuania in partnership with Vilnius City Municipality's Urban Development Department. ICT and virtual gaming support is provided by the researchers of the Department of Graphical Systems at VGTU. As a case study, VUS method is applied for verification of preliminary design of the Missionaries public park in Vilnius City (Figure 5). It combines $3 \mathrm{D}$ modelling and virtual space simulation with community involvement techniques and provides a tool for analysing and transcribing the results in a usable form.

The basic problem of designing Missionaries Park is its better social inclusiveness and response to the needs of local communities and all citizens. Municipal authorities that are responsible for the project are not sure if the draft programme for the park design is fully coherent with 


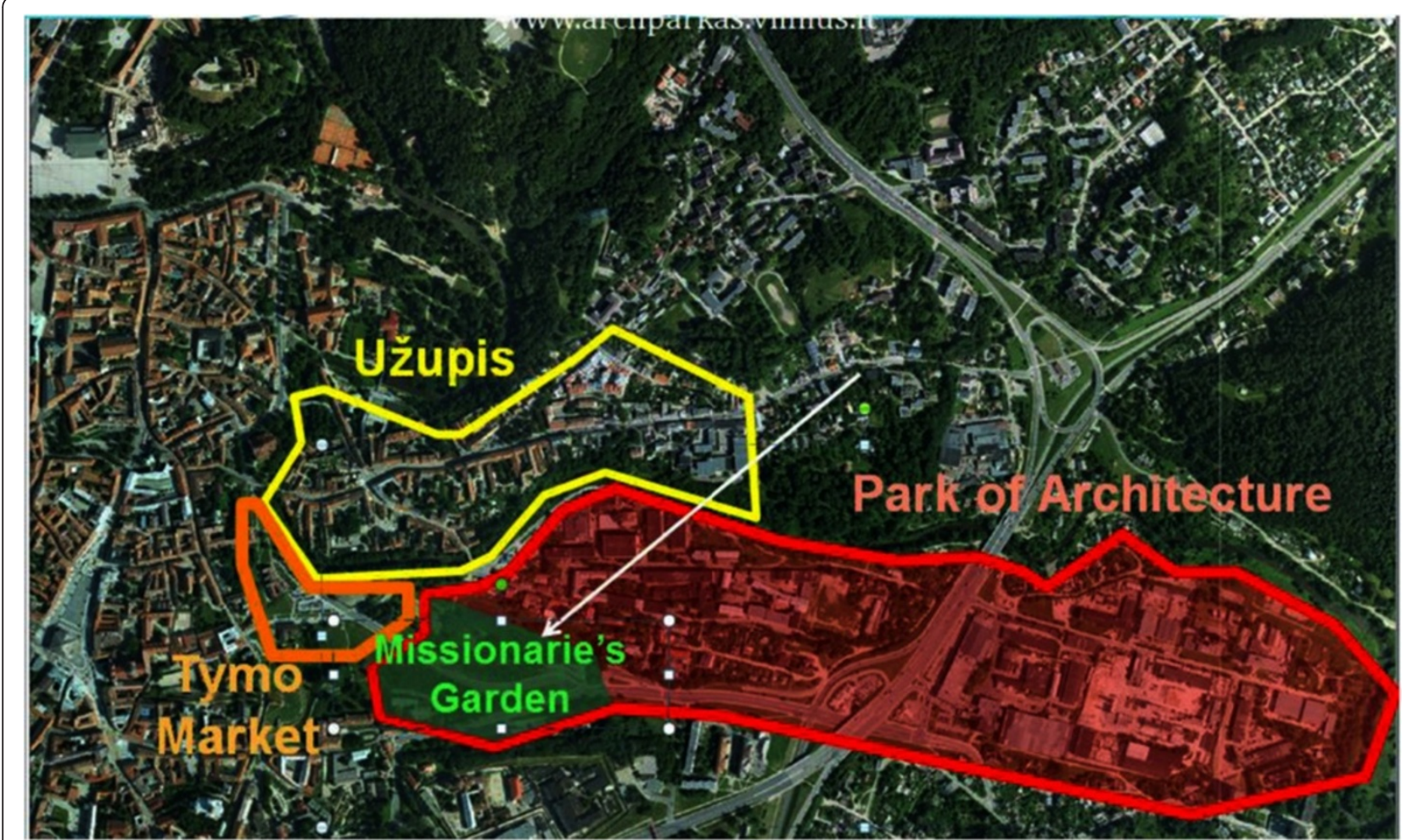

Figure 5 Location map of the VUS case study - Missionaries Park in Vilnius City. Property of Vilnius City Urban Development Department.

these needs and wishes to verify it with the citizens. The draft project of the park regeneration has been prepared and presented to professional community where it was evaluated in the aspect of professional quality. Still, social inclusiveness is the goal pursued by the local authority also for the reason to make construction and maintenance of the park easier by involving local business and public interest. The Missionaries site is located on the edge of Vilnius Old Town, at the site of the historic suburb. In fact, it is a central part of town within the historic residential area on one side and an abandoned industry facility on the other. The area is a part of the former Missionaries convent established on-site in the sixteenth century (Figure 5). Proper regeneration of the park with integrated services from the surrounding buildings is expected to bring one more recreational facility within the historic part of Vilnius City.

There were several basic features set as an initial aim of developing the new system for public participation in planning and design. Primarily, it is the immediate character of response that would allow eliminating uncertainties with participant's real opinion regardless of external influences. Secondly, it is possible to maintain access to the focus group of residents who, in our understanding, are interested in planning outcomes and impacts on their community. Thirdly, it is easily accessible for any user with a PC, laptop, tablet or even a mobile phone device used by the young and the elder, at home, office, public space or elsewhere. What is needed more is permanent access to the planning data on different stages of a project. From preliminary design to development plan, implementation, monitoring and feedback are main stages on which the efficiency of the system has to be designed, tested and evaluated.

The important step of the VUS project is setting the criteria for evaluating the plan. In the VUS case, the project team has developed two basic groups of aspects to be surveyed: efficiency of social environment in terms of space use, building integration and services, and the other group of criteria - visual emotional impact of environment with quality of space perception, visual impact of plants and quality of virtual representation (Figure 6). Both groups of criteria are equally important as they characterise the overall impression and opinion of the user at personal and community levels in functional and compositional aspects. The detailed list of criteria is developed to reflect on the social and visual aspects of the analysed park (Table 3). The concrete qualitative and quantitative information accumulated in the process of gaming is analysed and evaluated under all these criteria to provide the project group with the summary report on the four main aspects for the survey that are raised by the organiser and the client of this study - Vilnius City Municipality: how does the Missionaries Park would work for the needs of all Vilnius citizens, 


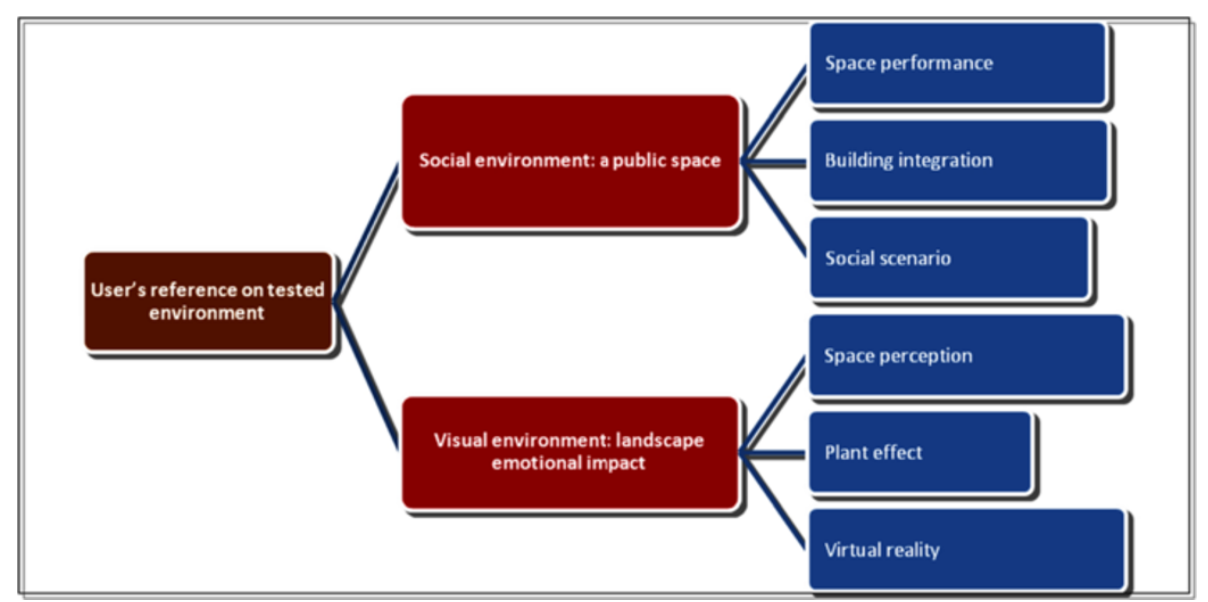

Figure 6 Criteria chart for analysing user's involvement in virtual urban simulation. By G. Stauskis.

how would it satisfy the needs of the local community, is the Park well shaped to host different types of events, and finally is it a safe place for recreation (Table 3)?

In order to build an efficient communication between Vilnius municipality as the client, community as the user and the research as the service provider, the VUS methodology was developed in the stages of preparation, involvement and analysis (Figure 7). The preparation phase included task assignment and selection of the project site, building up a 3D model (Figure 8) and providing it with gamification features with necessary functions and characters as movement and collision physics, interaction with environment elements, introduction of human characters and other features. During this phase, the municipality as the client gave the research group the task to check the preliminary plan and learn the importance of the designed park for the city and for the local community, to check its attractiveness for organising

\section{Table 3 Survey indicators for analysing virtual gaming information}

\begin{tabular}{|c|c|c|}
\hline Survey questions & Indicators & Score \\
\hline \multirow{4}{*}{$\begin{array}{l}\text { a. Can the designed Missionaries Park function } \\
\text { as the central recreation space of the city? }\end{array}$} & - Park is frequently used by all urban residents & 6 \\
\hline & - Park is the popular meeting and communication place & 6 \\
\hline & - Park with services from surrounding buildings is the family leisure place & 6 \\
\hline & - Spatial arrangement and plant design facilitate public communication in park & 5 \\
\hline \multirow{4}{*}{$\begin{array}{l}\text { b. Can Missionaries Park become the part of } \\
\text { life for local communities? }\end{array}$} & - Local residents daily visit the park & 6 \\
\hline & - Residents have their loved places and spaces in park & 6 \\
\hline & - Local residents organise their events in the Park & 6 \\
\hline & - Local residents take part in planning, construction and maintenance of the park & 5 \\
\hline \multirow{4}{*}{$\begin{array}{l}\text { c. Is Missionaries Park capable to attract } \\
\text { mass cultural and recreation events? }\end{array}$} & - Poetry, music and other festivals take place in the park & 6 \\
\hline & - Park spaces and plants attract wedding and other event photography & 6 \\
\hline & - Flower and other exhibitions and competitions take place in the Park & 5 \\
\hline & - Park spaces host cultural events of the neighbouring convent & 5 \\
\hline \multirow{2}{*}{$\begin{array}{l}\text { d. Can Missionaries Park become the } \\
\text { safe and secure place for recreation? }\end{array}$} & - All spaces in the park are attended by different groups of users & 10 \\
\hline & - Spatial arrangement of the park makes it free from areas for potential attack and vandalism & 10 \\
\hline \multirow[t]{6}{*}{ e. Other questions for the survey } & - Park entrances and fencing & 3 \\
\hline & - Pedestrian transit tracks across and in the park & 2 \\
\hline & - User-safe water features & 2 \\
\hline & - Features and services of surrounding buildings are frequently used & 2 \\
\hline & - Most popular viewpoints and visual connections to and from the park & 3 \\
\hline & Total score & 100 \\
\hline
\end{tabular}




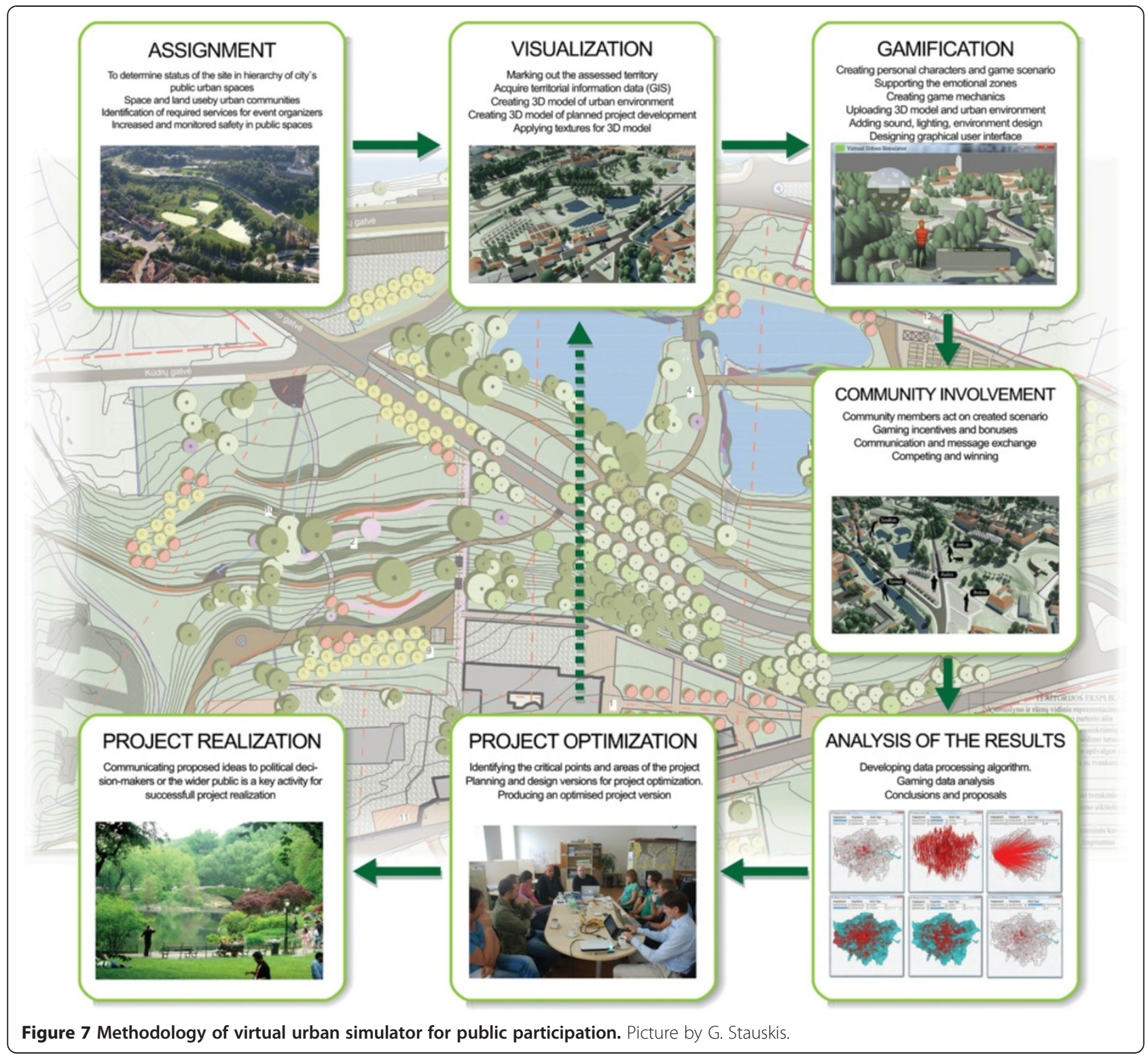

Figure 7 Methodology of virtual urban simulator for public participation. Picture by G. Stauskis.
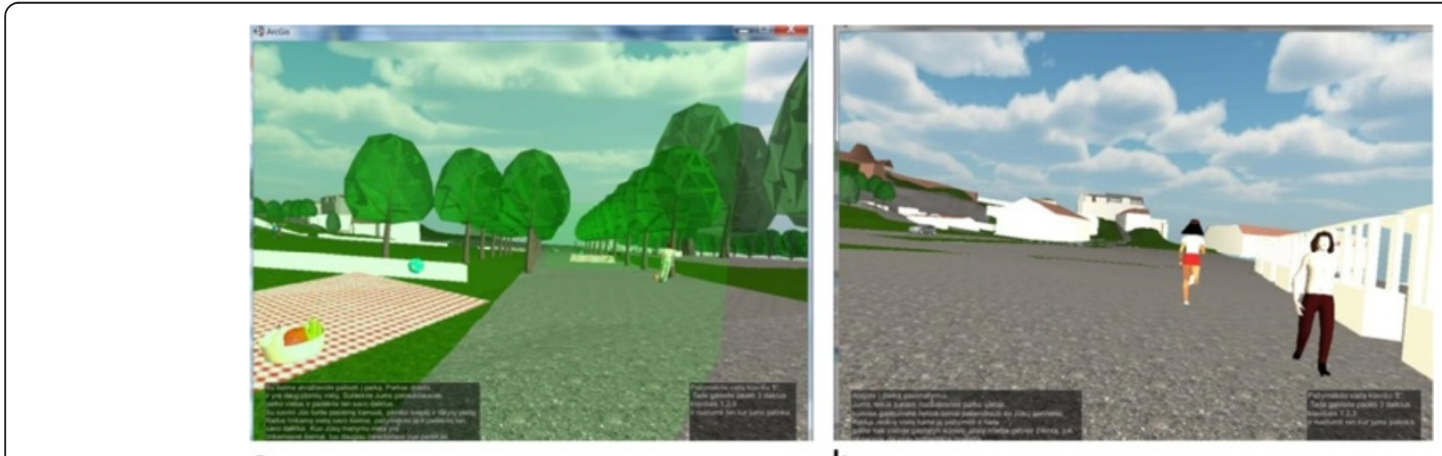

a

b

Figure 8 Frames of 'The Family' (a) and 'The Friends' (b) scenarios on the VUS models. Unity 3D software environment. Pictures by G. Stauskis. 
different events and also to evaluate its safety and security for its users. Every sub-phase is important to the overall success of the project application. Selecting a proper intake area gives the number of population to be involved into the process, and in the VUS case, it was limited to 10 min reach from the neighbouring urban blocks what is appropriate for the dense old town development with several other recreation areas in similar time distances. It might be different in, e.g. new residential environment where distances measured in travel time are greater. In the next phases of the project, the method of Space Syntax will be used to determine the proper intake area according to the typology of urban grid of the planned and neighbouring areas [17].

Participation phase is based on direct involvement of pre-selected residents and other stakeholders in the virtual gaming process by performing pre-designed tasks according to the game scenario. During the starting phase of the project, two scenarios were created: one built around the family recreation activities in the park and the other with recreation of group of friends in the park (Figure 8). In both cases, the users were given certain tools for analysis of the place and performance of the given scenario. In both cases, they could easily move around the park area within enclosed perimeter and select a preferred place for their family or friend's meeting by locating preselected recreation equipment and street furniture at preferred spots of the park area. The scope of tools was designed in a way which could provide the park designers with information about the most and the least attractive places of the park, track the movement of players across the park area to see the busiest tracks, and identify the most necessary public furniture for the park.

The analysis phase of VUS includes the data processing and analysis, interpretation of acquired results and their delivery to the project development team for their integration into the final design. The project database will be requested to give a response on data indicators directly related to the tasks of the client that were integrated into the gaming scenarios. The results are expected to put light on the importance, attractiveness and functionality of the planned public space. Finally, the results will be delivered to the planning team for discussions and decisions about the possible actions. In the case of excellent or very good results, the decision might be that the plan could be passed with no or minor additions and amendments. In the case of good or satisfactory results, the plan should be modified by the features pointed out as missing or weak in simulation and testing process. In the case of fair, poor or unsatisfactory evaluation results, the plan has to be seriously reconsidered starting with its aim and objectives, also all planning proposals including socio-economic and environmental planning consequences.
The presented project is still ongoing in its community involvement phase (Figure 7), and the analysis of results will follow in the next phases of research.

\section{Results and discussion}

The periods of development in public participation illustrate close relations between the historical development of urbanism and growth of civil society. Rapid urbanisation processes brought more people to cities where urban communities with specific lifestyle were developed, and the way how their residential areas were planned and designed gradually became part of social capital with informal rules and traditions of communication, space maintenance, safety and security. In order to keep and grow this value, the built environment of urban communities should be treated very sensitively during the redevelopment or refurbishment phases thus avoiding radical transformations and demolitions. Public participation is the link that provides planning organisers with the information from real living communities allowing to verify and eventually improve the design based on feedback information.

Even though there is a wide range of participation in planning tools and methods established in building legislation and used in planning practice, still there is little experience and research on the application of innovative and emerging public participation techniques, especially with the application of ICT possibilities. Researchers focus on general aspects of evaluation of 'serious games', on hazard recognition [18], environmental [19] and infrastructure spatial planning [20] and other related issues. Traditionally, the set of passive and relatively active methods and techniques prevail in different countries (Table 1). The direct interaction between the planning organiser and the participant in such meetings and committees has relatively low representativeness and reliability, as the events are usually dominated by the most active representatives of communities which usually have strong impact on the feedback from other residents. Usually, the opinions of residents are delivered in an indirect way, as participating activists try to express the opinion of other people who are absent at the taken moment. In this way, the process often has doubtful reliability and low representativeness in respect of users of the planning area. Moreover, the opinions of some groups of population as children, youth or people with disabilities have a rare chance to be heard and minded. In this context, the emerging interactive participation tools as listed in Table 4 are expected to close the mentioned gaps and make the public participation process more complete and its results more reliable and transparent for sustainable urbanism.

By analysing the methods of public participation, one can notice that each of them has strong sides and weak 
Table 4 Methods of reality representation for stakeholder involvement and public participation

\begin{tabular}{llll}
\hline Method & Traditional & Modern & Emerging \\
\hline Graphical & Drawing, drafting, painting & CAD linear drawing & Virtual reality simulation \\
Spatial & Building hard models, photography & Three-dimensional modelling, model rendering & Gaming, virtual role play, virtual cities \\
\hline
\end{tabular}

points; on the other hand, each of them activates a specific area in the community and checks the plan at a special angle. This takes us to an important finding that different tools of public participation should be used in complex by combining methods that are appropriate to the taken case and could give the best available results. To avoid duplication, the most fit-for-purpose methods have to be selected minding cultural, ethical, technical, social, and the other features both in the community and in the project.

In the situation when ICTs are more and more becoming a daily use feature, it is natural to involve them as one of the important tools to be used in public participation. Analysis of recent participation practices demonstrate that ICT-based tools can attract the groups of population that often fall out from the group of participants and give them a modern easily accessible tool using technologies and devices that are already at their disposal. At the very beginning, it should be clear about the strong features and the limitations of this tool as VUS or similar. Virtual reality is not a substitute to the real face-to-face interaction of citizens; it is a supportive tool with several very strong and efficient features as listed in this paper (efficiency, transparency, accessibility and resource consumption) that was missing among traditional instruments of public participation. ICT tools allow creating a multi-layer stakeholder platform that is an essential feature of planning job. Allowing the public into this circle makes the group more complete, and by ICT tools - more powerful in the decisions and the results.

It is essential to have proper software and technical support for the development of this kind of ICT-supported systems. The main dilemma in this phase is finding the best compromise between the systems that are most effective for space modelling on the one side and gaming process on the other. In the VUS case, Unity 3D was chosen as an efficient and comfortable gaming environment that opens wide opportunities in model building and optimisation. Usual drafting, modelling and rendering techniques could be used for the initial phases of the process, later converting the files to a programme supporting virtual gaming. It is essential to keep in order the GIS background and environment so as to get direct references to land sites and buildings in real urban locations.

By responding to the goals of transparency, immediacy, direct access, permanence and follow-up, VUS extends the methods of public participation and introduces a modern, efficient and reliable tool. Essentially, VUS is a new word in the development of interactive and interdisciplinary cooperation platform for public participation that is essential for efficient and effective urban planning and design as foreseen by Agenda 21 and the Aarhus convention in 1998 [21].

\section{Conclusions}

The presented VUS methodology is developed as an innovative tool to help Vilnius City Municipality, on small scale, to examine in an interactive way to what extent the project of Missionaries Park meets the interests of local and all the city's community. The latter will be given an opportunity to get acquainted with the project and report its opinions about all features of the project. Moreover, the method allows checking the planned facility on public attractiveness, functionality, safety and security and, if needed, making the necessary improvements. Lastly, the system enables local authority to establish a contact with potential event organisers and other small businesses in order to shape the park as a space fit for different types of public events that will also be an important feature for economic viability of the place. All together, it leads to more rational use of social and material resources as human labour, urban land, natural and construction materials, and energy.

As permanence and monitoring are important features of planning and design, VUS opens perfect possibilities to monitor the process of planning, construction and maintenance as it could be repeatedly used to indicate the preferred modifications while the facility is in use. There are many other possibilities how the VUS tool could deviate once taken into regular practice by local authorities, communities, businesses and moderated by researchers. Numerous lines of research are open to further development and investigation of specific features of melting public participation with virtual imaging and gaming. As the on-going VUS project already revealed, gaming feature is extremely attractive and involving an environment that could facilitate wider involvement of residents into public participation activities compared to traditional techniques. Interdisciplinary teams of researchers and practitioners are needed to creatively apply the knowledge from the fields of planning and architecture, urban sociology and anthropology, environmental science, ICT and related themes in order to increase the quality of plans and make the implementations more sustainable for the 
citizens and the environment in the process of construction, use and maintenance.

VUS as an interaction platform can drastically change the design, evaluation, teamwork and participation in planning and design and bring more sustainability instead of hierarchy to the process. VUS application has a high technology edge when the urban space is planned and designed. High visual quality of VUS models is essential to bring realistic familiarity with the realistic landscape image to seriously motivate and involve the user. Finally, the broader questions arise: whether new planning and interaction tools give too much control to the public over their decisions about the future of spaces and buildings usually planned and designed by urban planners and architects. The answers lie in the balanced socio-economic understanding of the roles and missions of architects and the public.

Looking forward, public participation could and should become a trendy exercise to be used actively; joining in ICT technologies is the way to its wider application. Popular and widely used tool would extend the number of users and make it more popular among the groups of young population rarely engaged in ordinary hearings, meetings and committees. In the long run, ICT-based public participation would transfer as a specific application to social media and offer plenty of easily accessible information and effective tools under moderate resource.

\section{Competing interests}

The author declares that he has no competing interests.

\begin{abstract}
Author's information
Gintaras Stauskis is a Doctor of the Humanities in Architecture and a professor at Vilnius Gediminas Technical University (Lithuania). He is conducting academic training and research activities at the Department of Urban Design, Traku str. 1, Vilnius LT-01332, Lithuania. He is involved in the European Union research programmes on Green Building and sustainable urbanism. He is the Head of Lithuania Green Building Council LTGBC and a member of the editorial board of the Journal of Civil Engineering and Architecture (USA), Landscape Architecture and Art (Latvia) and Arhitektura un Pilsetplanošana (Latvia). His current research fields include landscape architecture and planning, 'green' urban architecture and mobility, accessibility of environment, recreation and urban health. His research results have been presented in numerous national and international publications and conferences.
\end{abstract}

Received: 11 September 2013 Accepted: 19 March 2014 Published: 17 April 2014

\section{References}

1. Hackney R (1990) The good, the bad and the ugly. Frederick Muller, London

2. Communities in Control (2008) Real people, real power. Crown copyright. Electronic resource. http://www.openeyecommunications.com/wp-content/ uploads/CommunitiesinControlFull.pdf. Accessed 25 Aug 2013

3. Sheppard SRJ (1989) Visual simulation: a user's guide for architects, engineers and planners. Van Nostrand Reinhold, New York

4. Simpson DM (2001) Virtual reality and urban simulation in planning: a literature review and topical bibliography. J Plan Lit 15:3

5. Papasarantou C, Bourdakis V (2012) Represent-ing presence, V!RUS, n. 8. http://www.nomads.usp.br/virus/virus08/?sec=4\&item=4\&lang=en. Accessed 19 August 2013

6. Sheffield Development Framework (2006) Statement of community involvement. Sheffield City Council, Sheffield
7. Statement of Community Involvement and Planning Applications (2004). Office of the Deputy Prime Minister, London. http://www.communities.gov. uk/corporate/. Accessed 30 July 2013

8. Painting the Landscape (2009) A cross-cultural exploration of publicgovernment decision-making. International Association of Public Participation. http://c.ymcdn.com/sites/www.lap2.org/resource/resmgr/imported/Kettering_ FINALExecutiveSummaryReport.pdf. Accessed 25 Aug 2013

9. Visuomenès dalyvavimo teritoriju planavimo procese nuostatai (2004) [Guidelines on public participation in territory planning]. Lietuvos Respublikos Vyriausybès 1996 m. rugsejo 18 d. nutarimas Nr.1079 (Lietuvos Respublikos Vyriausybès 2004 m. liepos 16 d. nutarimo Nr. 904 redakcija) [Approved by the Decree of the Government of Lithuania No. 1079 from 18.09.1996 (Version Decree of the Government of Lithuania No. 904 from 16.07.2004)]. http://www3.Irs.tt/pls/inter3/dokpaieska.showdoc_l? p_id $=237982 \& p \_q u e r y=\& p \_t r 2=.15$ May 2013

10. The European Commission (2003) Directive 2003/35/Ec of the European Parliament and of the Council providing for public participation in respect of the drawing up of certain plans and programmes relating to the environment and amending with regard to public participation and access to justice Council Directives 85/337/Eec and 96/61/Ec. http://www.enviros. cz/ippc/AIP_smernice_2003_37_ES_20031007.pdf. Accessed 25 Aug 2013

11. Vilnius Gediminas Technical University (2013) Hotel DZÜKIJA in Druskininkai. Part of the Grand Spa Lithuania complex. http://www.construction21.eu/ case-studies/lt/hotel-dzkija-in-druskininkai-part-of-the-grand-spa-lithuaniacomplex.html. Accessed 23 Aug 2013

12. Liggett $R$, Friedman $S$, Jepson W (1995) Interactive decision making in a virtual urban world: visual simulation and GIS. In: Proceedings of the 15th ESRI user conference. Palm Springs. 24 Feb 2003

13. Bartlett WK, Neumann A, Meifort J (2005) Interactive landscape planning results of a pilot study in Koenigslutter am Elm, Germany. Proceedings/ Tagungsband; Ed./Hg.: Manfred SCHRENK. CORP 2005 \& Geomultimedia05. http://www.researchgate.net/publication/228863270_Interactive_ Landscape_PlanningResults_of_a_pilot_study_in_Koenigslutter_am_ Elm_Germany. Accessed 25 Aug 2013

14. Ruffat S, Ter Minassian H (2012) Video games and urban simulation: New tools or new tricks? Eur J Geogr. article no. 622. http://cybergeo.revues.org/ 25561?lang=en. Accessed 25 Aug 2013

15. Dhingra Ch KRSR (2013) Establishing a multi-stakeholder forum for urban mobility. UN-Habitat, EMBARQ, Washington

16. Manneh C (2012) Computer game provides inspiration for new planning tool. Cities Today 7:43

17. Bučys J (2013) Funkcinių Ir kompozicinių urbanistinès struktüros analizès aspekty sujungimas: vilniaus miesto lokaliy centry tyrimas. [Combining functional and compositional aspects of the analysis of urban structure: a case study of local centres in Vilnius]. J Arch Urbanism 37(2):69-87. doi:10.3846/20297955.2013.807565

18. Mayer IS, Wolff A, Wenzler I (2013) Learning efficacy of the 'hazard recognition' serious game: a quasi experimental study. In: Serious games development and applications. Springer, Heidelberg, pp 118-129

19. Nefs M, Gerretsen P, Dooghe D, Mayer IS, Meijer SA (2010) Gaming the interrelation between rail infrastructure and station area development: part 1 - modeling the serious game 'SprintCity'. In: Third international conference on infrastructure systems and services: next generation infrastructure systems for EcoCities. 11-13 Nov 2010

20. Zhou Q, Mayer IS (2010) Gaming as the method to integrate modelling and participatory approaches in interactive water management. In: International Environmental Modelling and Software Society (iEMSs) 2010 International congress on environmental modelling and software modelling for environment's sake, fifth biennial meeting. International Environment Modelling and Software Society iEMSS, Ottawa

21. United Nations Economic Committee for Europe (1998) Convention on access to information, public participation in decision-making and access to justice in environmental matters. http://www.unece.org/fileadmin/DAM/ env/pp/documents/cep43e.pdf. Accessed 25 Aug 2013

\section{doi:10.1186/2192-0567-4-7}

Cite this article as: Stauskis: Development of methods and practices of virtual reality as a tool for participatory urban planning: a case study of Vilnius City as an example for improving environmental, social and energy sustainability. Energy, Sustainability and Society 2014 4:7. 